\title{
Vuoi tu venire in Merica? Venturas e desventuras da imigração italiana em São Carlos
}

\author{
Ailton Pereira Morila
}

\section{Addio Italia}

Giovanni Polese saiu de S. Povo in Piave, entre Veneza e Treviso na região do Vêneto, Itália, no começo de 1888. Não saiu sozinho. Trouxe consigo sua esposa Teresa e os seus 7 filhos: Anna, a única menina, e Angelo, Domenico, Gio-batta, Giussepe, Lorenzo e Primo. Deixou para trás seu pai e outros membros de sua família. Uma das tragédias da emigração.

Valentino Piovesan saiu de Melina, um pequeno bairro rural da provincia de Treviso, na Região do Vêneto, no final de 1888. Com ele vieram seus filhos Alessandro, Angela e Antonio e sua esposa Maria. Trouxe também sua irmã Caterina, seu pai Giovanni e um sobrinho, Giovanni. Sua irmã Maria já estava no Brasil há cerca de dois anos, trabalhando em uma fazenda em São Carlos, interior de São Paulo. Deixaram na Itália muitos amigos.

Sigamos os passos dessas duas famílias a partir das cartas enviadas por esses a seus parentes na Itália. Ao longo do texto, outros irão aparecer. Essas cartas se encontram na obra de Franzina ${ }^{2}$, que as recolheu e organizou na Itália. Essa correspondência é extremamente rica e ainda insuficientemente estudada. Este artigo é uma contribuição neste sentido. Foram escolhidas cartas de imigrantes da região de São Carlos, interior de São Paulo. Voltemos a Valentino e Giovanni.

\footnotetext{
${ }^{1}$ Professor do Departamento de Educação e Ciências Humanas do CEUNESUFES. apmorila@gmail.com

2 FRANZINA, Emilio. Merica! Merica! Emigrazione e colonizzazione nelle lettere dei contandini Veneti in America Latina 1876-1902. Milano: Feltrinelli, 1979. 
Alvim $^{3}$ aponta o esfacelamento familiar de boa parte dos imigrantes, que, ao saírem de sua terra natal, deixaram amigos e parentes. Giovanni parece ter tido sorte neste sentido. Ao que parece conseguiu sair com seu núcleo familiar inteiro, trouxe a esposa e os filhos. Deixou amigos, o pai e outros parentes. Valentino conseguiu maior feito, reuniu boa parte da família no Brasil. Não era incomum um esfacelamento ainda maior. Uma canção da época demonstra bem isso:

\section{(...)}

Quando l'alber comincia a fiorire

la primavera sta per partire,

amante mio tu mi lasci sola

e Dio sa quando ritomerai.

(...)

Quando sarai via nell'America,

tu sposerai un'americana,

non penserai più di me italiana,

e dell'amore che t'ho portà

\section{(...) \\ e maledetta ne sia la macchina, \\ il macchinista e la ferrovia \\ che m'ha rubato l'amante mio \\ e chissà mai se ritornerà! ${ }^{4}$}

Muitas canções italianas do período fazem referência ao esfacelamento familiar. Essa é apenas uma. O desespero de uma mulher que ficou enquanto seu amor partiu. O final

${ }^{3}$ ALVIM, Zuleika M. F. Brava Gente! Os italianos em São Paulo 1870-1920. 2. ed., São Paulo: Brasiliense, 1986.

${ }^{4}$ CAPRARA, Loredana. Cultura e língua italiana nas músicas populares dos séculos XIX e XX. São Paulo: Humanitas, 1997, p. 37. Trad.: Quando a árvore começa a florir / a primavera está preste a partir / amante meu você me deixa sozinha / e sabe Deus quando voltará. (...) Quando estiver longe na América / você esposará uma americana, / não pensará mais em mim, italiana... / nem no amor que eu dei prá você / E maldita seja "a máquina" / "o maquinista" e a ferrovia, / que roubou o meu amante... / e quem sabe se jamais voltará! 
desta canção é incisivo e mostra que a situação não será passageira: "E quem sabe se jamais voltará".

Zuleika Alvim ${ }^{5}$, ao estudar a imigração italiana para São Paulo, aponta para a necessidade de entender o movimento como um todo, por mais que o binômio emigração-imigração pareça uma ruptura para os próprios protagonistas. ${ }^{6}$

Mas quais as razões que levaram Giovanni, Valentino e um sem número de italianos a emigrar? E mais, quais os sentimentos envolvidos nessa emigração?

O poema I va in Merica, do socialista italiano Berto Barbarani, nos indica essas razões:

Fulminados por um relampâgo durante uma tempestade, a erva dos prados em grande parte secas, queimadas as videiras por doença, que nunca deixam os camponeses em paz. Hipotecado tudo o que resta, com o trigo que não vale quase nada, todo vilarejo sofre a sua agonia e toda família tem um pelagrosso! Morta a vaca que dava o queijo, morta a mulher ao parir uma filha, protestada a promissória pelo tabelião. Num feriado, à noite, fechado na taberna com um grande murro na mesa: "Porca Itália", blasfemam, "vamos embora".

Contam-se todos. Quantos somos?

- Apenas dez que podem suportar o cansaço; o resto são mulheres com bebês nos braços, $o$ resto, velhos e crianças,

\footnotetext{
${ }^{5}$ ALVIM, Op. Cit., 1986.

${ }^{6}$ Franzina inaugura essa questão. Analisando cartas enviadas por italianos residentes na América, percebe que uma das funções dessa correspondência é manter os laços de parentesco e solidariedade, que ficaram prejudicados pela separação. A manutenção de uma correspondência regular com os parentes pode ser encarada portanto como uma necessidade de relativizar ou amenizar a ruptura causada pela emigração. Nesse sentido, a historiografia social, quando procura resgatar a imigração como um todo, parte de um pressuposto dos próprios sujeitos da emigração-imigração. FRANZINA, Op. Cit., 1979. 
mas ficando aqui não comemos não, por Deus.

Será preciso também dar esse grande passo,

Se no inverno tivermos gelo,

pobres de nós, será uma tragédia!

- Em outubro, carregados de fardos,

depois de terem falado mal de todos os senhores,

depois de terem bebido três ou quatro copos,

com a cabeças confusa, embriagada,

Apóiam-se uns nos outros

e, cambaleando, vão pela estrada. ${ }^{7}$

Esse poema expõe as condições na Itália no período da imigração, ao mesmo tempo em que revela o estado de espírito dos italianos para emigrar. Inicialmente vieram os pequenos proprietários vênetos, considerado o primeiro fluxo imigratório, até 1885 . Em seguida vieram os braccian$t t^{8}$ setentrionais, o segundo fluxo imigratório, de 1885 a 1902. Alvim procura mostrar as condições de vida desses "italianos" e as razões que levaram muitos destes a emigrar. Descreve o regime de trabalho familiar dos vênetos e as condições cada vez mais precárias de sobrevivência, fruto da expansão do capitalismo que caminhou paralelamente à emigração:

Do lado expulsor, a Itália, isso se explica pela forma como ocorreu a penetração capitalista no campo: concentração da propriedade; altas taxas de impostos sobre a terra, que impeliram o pequeno proprietário a empréstimos e ao conseqüente endividamento; oferta, pela grande propriedade, de produtos a preços inferiores no mercado, eliminando

\footnotetext{
7 FRANZINA, Emilio. A grande imigração: o êxodo dos italianos do Vêneto para o Brasil. Campinas: EdUnicamp, 2006, p. 318.

${ }^{8}$ Braccianti eram os trabalhadores assalariados, que se dividiam em anuais e diaristas. Segundo Alvim, os braccianti com contrato anual tinham condições de salário e, portanto de vida, melhores que os diaristas, que boa parte do ano não tinham trabalho. ALVIM, Op. Cit., 1986.

9 Alvim ressalta que a Itália nesse momento é um conjunto não uniforme de regionalidades, e cada qual com suas particularidades. Já que se tornaria impossível não utilizar a palavra italiano, ao menos para designar este conjunto não uniforme, a palavra foi utilizada aqui entre aspas. Toda vez que aparecer no texto, devemos estar atentos a isto. ALVIM, Op. Cit., 1986.
} 
a concorrência do pequeno agricultor; e, finalmente, a sua transformação em mão-de-obra para a indústria nascente. ${ }^{10}$

Na poesia, percebemos essa expansão capitalista pelo trecho: "Hipotecado tudo o que resta, com o trigo que não vale quase nada (...) protestada a promissória pelo tabelião". Outras condições, relativas à transformação da natureza, também são importantes para a compreensão da emigração, tais como devastação de florestas, que acabaram por modificar o regime pluvial, causando excesso de chuvas nas planícies e escassez nas montanhas e colinas. Elas estão explícitas na poesia: "Fulminados por um relâmpago durante uma tempestade, a erva dos prados em grande parte secas, queimadas as videiras por doença, que nunca deixam os camponeses em paz". E ainda a expansão demográfica e a impossibilidade de essa população ser absorvida pela economia italiana. Particularmente o Vêneto, segundo Alvim, sofreu com este quadro, sendo que a pequena propriedade tornou-se sinônimo de pobreza ${ }^{11}$. Completando o quadro, no plano internacional, a "grande depressão", de 1873 a 1895.

Essas são as condições em que se encontravam a Itália e os pequenos proprietários vênetos, que sofreram a perda não só de suas propriedades, de seus pertences, mas também dos seus familiares: "morta a vaca que dava o queijo, morta a mulher ao parir uma filha", desfizeram-se do pouco que lhes restava a fim de angariar fundos para emigrar, vendendo seus animais, utensílios domésticos e a última colheita do trigo, no outono, e partindo entre setembro e novembro.

Esse primeiro contingente imigratório utilizou os parcos recursos obtidos pela venda de seus últimos pertences para então emigrar. O segundo contingente imigratório foi composto principalmente pelos braccianti, que nada possuiam, e que só conseguiram emigrar com a passagem subsidiada. Assim, conforme Alvim, "sem nada mais a perder,

\footnotetext{
${ }^{10}$ ALVIM, Op. Cit., 1986. p. 22.

${ }^{11}$ Ibid.

198 Revista de História Regional 15(1): 194-228, Verão, 2010
} 
esses camponeses não hesitavam em fugir desse estado de perene miséria." 12

Giovanni Polese e Valentino Piovesan parecem então exceções. Vênetos de origem emigraram em 1888, portanto no segundo fluxo imigratório. A estada na Hospedaria dos Imigrantes em São Paulo indica que tiveram sua passagem subsidiada. Teriam eles tentado sobreviver mais um pouco frente à expansão capitalista enquanto muitos ao seu redor emigravam ainda com algum dinheiro? Se for esse o caso, a tentativa de luta não parece ter logrado êxito, pois se viram obrigados a emigrar mais tarde. Talvez já houvesse perdido tanto que não sobrara dinheiro algum para embarcar com toda a família. Quando a emigração passou a ser subsidiada, teriam visto uma tábua de salvação. De qualquer forma quaisquer que sejam as razões particulares de Giovanni Polese e Valentino Piovesan, suas respostas frente à situação italiana têm um componente comum para todos os emigrantes: a luta. Luta pela sobrevivência, que, segundo Alvim, é "uma manifestação de luta de classe. Foi a fuga de uma situação de incrível miséria, sem dúvida, que impeliu esses homens a deixarem a sua pátria em busca de um destino melhor; não foi uma luta sem a consciência do que lhes sucedia" ${ }^{13}$.

Entendida a emigração como uma luta de classes, como uma luta possivel, é que se pode compreender a atitude da classe dirigente italiana em aceitar, e até facilitar a emigração como o menor dos males, pois a saturação demográfica, a crise econômica e o pauperismo configuravam uma situação potencialmente perigosa para uma Itália recém-unificada e seu novo governo. Assim a emigração tornou-se uma válvula de segurança que permitia aliviar esta situação.

Retomando o poema I va in Merica, podemos perceber o quanto ele sintetiza a situação italiana. Ao lado das catástrofes naturais, como as tempestades e pragas, encontram-se os fatores de expansão do capitalismo, que atingem principalmente os pequenos proprietários: a alta e baixa dos pre-

\footnotetext{
${ }^{12}$ Ibid., p. 57-8.

${ }^{13}$ Ibid., p. 128.
} 
ços, a hipoteca, o protesto da promissória. O sentimento de revolta se expressa: "Porca Itália". E "depois de ter falado mal de todos os senhores", a solução, ou melhor, a tentativa de sobrevivência é enunciada: "vamos embora".

Assim, as famílias Polese e Piovesan cantaram ou ouviram cantar a canção:

\author{
Guarda Venezia \\ Come la é bella, \\ Sembra una stella \\ Lá in mezzo ai mar. ${ }^{14}$ \\ Enquanto que os Toscanos cantaram:
}

Quanto tu sei bellina

Vestita da guerriero

Per quel sembiante altero

Io ti vorrei sposar. ${ }^{15}$

E os Napolitanos:

Addio, mia bella Napoli D’ogni cittá regina... ${ }^{16}$

O Bispo italiano Scalabrini que esteve no Brasil no período e estudou a imigração nos descreve com detalhes a cena de despedida:

\footnotetext{
Passando pela estação, vi o salão, os pórticos laterais e a praça vizinha tomados por trezentas ou quatrocentas pessoas mal vestidas, divididas em diversos grupos. Sobre suas faces bronzeadas pelo sol e sulcadas pelas rugas precoces que a penúria sói imprimir, transparecia a agitação dos sentimentos que invadiam seus corações naquele momento. Eram anciãos

${ }^{14}$ CENNI, Franco. Italianos no Brasil. 2. ed., São Paulo: Martins/Edusp, 1975, p. 177-8. Tradução: Veja Veneza / Como é bela, / Parece uma estrela / Lá no meio do mar.

15 Ibid., p. 177-8. Tradução: Como você é bonita / Vestida de guerreira / Como semblante altivo / Eu gostaria de te desposar.

16 Ibid., p. 177-8. Tradução: Adeus, minha bela Nápoles, / De todas as cidades, és rainha. . 
curvados pela idade e pelas fadigas; homens na flor da idade; senhoras que arrastavam os filhinhos atrás de si, ou os carregavam ao colo; meninos e meninas... todos irmanados por um só pensamento e guiados para uma única meta. ${ }^{17}$

E é assim que estes italianos se despedem da Itália, constituindo o que Alvim chama de "diáspora moderna"18, mesclando sentimentos de saudade como nas canções precedentes, e sentimentos de revolta. Mas para onde vão estes italianos?

Italia bella, mostrati gentile

e i figli tuoi non li abbandonare se no ne vanno tutti in Brasile, non si ricordan piú di ritornare Ancor qua ci sarebbe da lavorar senza stare in America a migrar Il secolo presente qui ci lascia, il millenovecento s'avvicina. La fame ci han dipinta sulla faccia e per guarirla non c'è la medicina. Ogni Po' noi si sente dire: io vo là dov'è la raccolta del caffé... ${ }^{19}$

A fome estampada na cara, a falta de emprego ("Aqui mesmo ter-se-ia no que trabalhar"), a falta de perspectiva ("para curá-la remédio não há") aponta a direção ("vão todos para o Brasil”).

\footnotetext{
${ }^{17}$ SCALABRINI, João Batista. A emigração italiana na América. Caxias do Sul: Univ. Caxias do Sul, 1979, p. 43.

${ }^{18}$ ALVIM, Op. Cit., 1986, p. 19.

19 CAPRARA, Op. Cit., 1997, p. 33-34. Tradução de Zuleika Alvim: Itália bela, mostre-se gentil / e os filhos seus não a abandonarão, / senão, vão todos para o Brasil, / e não se lembrarão de retornar. / Aqui mesmo ter-se-ia no que trabalhar / sem ser preciso para a América emigrar. / O século presente já nos deixa, / o mil e novecentos se aproxima / A fome está estampada em nossa cara / e para curá-la remédio não há / A todo momento se ouve dizer: / eu vou lá, onde existe a colheita do café.
} 


\section{Ciao Brasile}

O destino destes emigrantes é um só:

Andiamo in 'Merica. . . . .

Andiamo a raccogliere caffé

Andiamo in 'Merica... 20

Assim Giovanni Polese, Valentino Piovesan e suas famílias, bem como um enorme contingente de pessoas, se dirigiram para a "Merica" como diziam. Os grandes polos de atração eram os Estados Unidos da América, a Argentina e o Brasil, como apontou a canção anterior ("vão todos para o Brasil").

Aos sentimentos de revolta e saudade da terra natal somam-se as esperanças e expectativas. Despedindo-se então da Pátria, canta-se a chegada:

Da l'Italia noi siamo partiti siamo partiti col nostro onore

trenta sei giorni di macchina e vapore

e em América siamo arrivà

Merica merica merica

Cossa sarala sta merica

merica merica merica

un bel mazzolino di fior

Nella merica siamo arrivati

no abiam trovato ne paglia e ne fieno

abbiam dormito sul nudo terreno

come le bestie abbiamo riposa

L'America l'è lunga e l'è larga

a l'è fata de monti e de piani

\footnotetext{
${ }^{20}$ CENNI, Op. Cit, 1975, p. 177-8. Tradução: Vamos à América. . . / Vamos apanhar café / Vamos à América.. 
Vuoi tu venire in Merica? Venturas e desventuras da imigração..

e com l'industria dei nostri Italiani

abiam formato paesi e città ${ }^{21}$

Mas por que emigrar para a América? Por que enfrentar "trenta sei giorni di macchina e vapore", ou seja, mais de um mês viajando de navio? E não era de maneira alguma uma viagem tranquila, conforme alertou Giovanni Polese: "morreram tantos de variola e os pequenos se ressentiram do navio e morreram quase todos." 22

As condições italianas apontavam para uma necessidade de luta, e essa luta se expressou em parte na emigração, como vimos. Mas para que a emigração fosse possivel, existiu em contrapartida interesse em receber os emigrantes, e mais ainda, houve interesse em acenar com a possibilidade de uma vida melhor, de retomada de certos valores tidos como fundamentais para esses italianos, como observou Souza:

Intencionalmente, a propaganda da imigração visava a famílias, no intuito de utilizar o trabalho familiar como maneira de barateamento do custo de mão-de-obra e estratégia de fixação do imigrante nas fazendas de café. Sob um outro aspecto, a eficiência e o sucesso dessa propaganda dependeu do fato de coincidir com expectativas do imigrante de conservar a família como uma unidade produtiva, como no caso, por exemplo, dos pequenos proprietários do Vêneto, ou de recuperá-la, como no caso dos braccianti da Itália Meridional - ambos ameaçados pela introdução de relações capitalistas no campo italiano ${ }^{23}$.

\footnotetext{
${ }^{21}$ Le Canzoni Italiane Di Sempre. São Paulo: [s.n.], [19-], p. 119. Tradução: Da Itália nós partimos / nós partimos com nossa honra / trinta e seis dias de máquina e vapor / e na América nós chegamos / Merica merica merica /Que coisa será esta merica / merica merica merica / um bonito buquê de flor / Na América nós chegamos / não achamos nem palha e nem feno / dormimos no desnudo terreno / como as bestas repousamos / A América é extensa e ampla / encantada de montanhas e de planície / e com a indústria de nossos italianos / Formaram paises e cidade.

${ }^{22}$ FRANZINA, Op. Cit., 1979. p. 151

${ }^{23}$ SOUZA, Maria Cecilia Christiano Cortez de. Crise familiar e Contexto Social: São Paulo, 1890/1930. Tese (Doutorado em educação), FEUSP, São Paulo, 1989, p. 138.
} 
Certamente, a possibilidade de manutenção do núcleo familiar e reestruturação do mesmo como unidade produtiva foi uma razão que Giovanni Polese e Valentino Piovesan consideraram.

Para tanto a propaganda imigrantista utilizou métodos como estimular a vinda de pessoas cujas famílias já se encontravam no Brasil ${ }^{24}$, mostrando um conhecimento das condições do campo italiano e da penúria dos camponeses. Acenando com a possibilidade de reconstrução dos núcleos familiares, incentivando a vinda de parentes, firmando contratos familiares nas fazendas paulistas, a propaganda imigrantista atinge dessa maneira as expectativas desses imigrantes.

Mas não era só isso que a propaganda imigrantista prometia:

Basta dizer aos camponeses que dentro de alguns meses terão dinheiro aos montes, que num par de anos serão proprietários de latifúndios, que, de trabalhadores braçais tornar-seão patrões, e conseguir persuadir uma meia dúzia dos mais importantes, o apostolado está completo (...). E assim, aos gritos de "viva a América" (...) "morram os patrões", levas de emigrantes deixaram a região dirigindo-se para o Brasil. ${ }^{25}$

Com um contingente de agentes e sub-agentes que alcançava a cifra de 20 mil pessoas, que atuavam na publicação de anúncios em jornais, manuais de emigração, nos contatos diretos com grupos de italianos, na escolha e organização dos emigrantes que iriam embarcar, com um discurso voltado para as expectativas do emigrante, podemos entender como o grupo cafeicultor paulista conseguiu atingir seus objetivos:

Pode-se constatar, assim, que, adaptando seus métodos de arregimentação aos diferentes momentos da penetração

\footnotetext{
${ }^{24}$ É nas cartas dos imigrantes, organizadas e analisadas por Franzina, que podemos perceber claramente este ponto. Entre as correspondências enviadas da América para a Itália, há em muitas o assunto da vinda de parentes, arranjos para trabalhar com o mesmo patrão e promessas de auxílio mútuo.

${ }^{25}$ Atti della Giunta per la Inchiesta Agraria e sulle Condizioni della Classe Agricola, 1882 Apud ALVIM, Op. Cit., 1986, p. 44. 
capitalista no campo italiano, o grupo cafeicultor paulista conseguia solucionar seu problema da mão-de-obra nas fazendas. Seguindo o traçado dessa expansão capitalista e o roteiro das várias fases da luta pelo poder entre as facções políticas paulistas, podemos compreender, então, por que as grandes famílias de meeiros, de arrendatários e de pequenos proprietários optaram pelo Brasil diante da crise que assolava o campo italiano e por que, posteriormente, as fazendas paulistas foram inundadas pelos antigos braccianti italianos. ${ }^{26}$

A possibilidade de reestruturação familiar e de independência econômica é expressa nos versos: "A América é extensa e ampla / encantada de montanhas e de planície". E, principalmente, nos versos: "e com a indústria de nossos italianos / Formaram países e cidades". Essas passagens indicam uma possivel solução dos problemas para estes imigrantes, e a propaganda imigrantista soube aproveitar-se disso, aliando sempre que possível ao imaginário "país de cocanha", analisado por Burke:

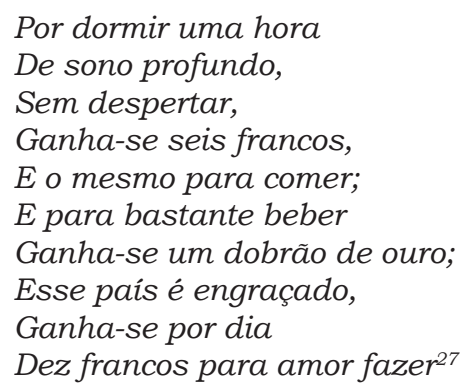

Porém essa propaganda não revelou aos imigrantes o que a canção revela: "Na América nós chegamos / não achamos nem palha e nem feno / dormimos no desnudo terreno / como as bestas repousamos". Mas essa é uma realidade que os imigrantes não tardaram a conhecer.

${ }^{26}$ ALVIM, Op. Cit., 1986, p. 60-1.

${ }^{27}$ BURKE, Peter. Cultura popular na idade moderna. São Paulo: Companhia das letras, 1989 , p. 214 

gente?

Mas afinal por que o Brasil necessitava de tanta

Os discursos oficiais e as discussões no legislativo apontavam para ausência de mão-de-obra, ou "falta de braços", no dizer das elites. Por muito tempo esse discurso foi incorporado à historiografia sem crítica alguma e, infelizmente encontra-se arraigado no senso comum. Estudos mais recentes apontam, entretanto, em outra direção.

O sistema escravista brasileiro apontava já no início do século XIX seu esgotamento. Mas é em 1850, com a proibição do tráfico negreiro, que desencadearia uma série de medidas que garantiriam a transição lenta e gradual para o trabalho assalariado. As diversas leis que se seguiram (Lei de terras, Ventre Livre, Lei dos sexagenários, Lei de Serviços) serviram de um lado para que a transição fosse suave e de outro para arrefecer as exigências dos escravos que cada vez mais se revoltavam com a situação. ${ }^{28}$

O fim anunciado da escravidão colocava um problema para os fazendeiros: como manter esta mão-de-obra trabalhando, e mais, em condições proveitosas para o fazendeiro?

É nesse sentido que foi pensada a imigração. Despejar no Brasil, e em especial em São Paulo uma quantidade tão grande de gente que garantiria aos fazendeiros a contratação de uma mão-de-obra barata.

O primeiro passo para esta empreitada foi dado já em 1850, com a lei de terras. A lei de terras transformou a terra no Brasil em mercadoria, impedindo o acesso à terra aos ex-escravos e também aos imigrantes que vieram. Desta maneira tanto o negro quanto o imigrante tiveram que se submeter ao trabalho assalariado.

\footnotetext{
${ }^{28}$ Vários são os autores que trabalham a mobilização negra como fator decisivo para o fim da escravidão. A maior mobilização negra seria responsável pelo fim "precoce" da imigração em algumas cidades. Assim Santos decretou a abolição em 1886 e São Carlos, em 1887. Ver DEAN, Op. Cit., 1977 e DIAS, Janaina. Crime e suicídio no final da escravidão em São Carlos do Pinhal (1869-1888). Trabalho de Conclusão de Curso (Graduação em História), Unicep, São Carlos, 2002. 
O próximo passo foi escolher a nacionalidade do imigrante. As discussões foram imensas. Pensou-se em chineses e africanos, tentou-se alemães e suiços. ${ }^{29} \mathrm{O}$ governo Imperial relutava em trazer protestantes e não brancos, mesmo porque o Império pensava em criar colônias para garantir fronteiras e "civilizar" o Brasil. Os fazendeiros pouco se interessavam pela nacionalidade, língua, religião ou saber anterior, queriam muitos "braços" para garantir um exército de mão-de-obra de reserva. O italiano mostrou-se um elemento que satisfazia as exigências das duas correntes. Branco e católico $^{30}$. Somam-se a isso as condições de expulsão da Itália.

Os fazendeiros paulistas se organizaram e fundaram a Sociedade Promotora de Imigração em 1886.

À Sociedade Promotora de Imigração, cabia a organização da imigração, sendo responsável por introduzir aproximadamente 120.000 imigrantes até o seu desaparecimento em 1895. Organizava a propaganda, a vinda de imigrantes e administrava a Hospedaria de Imigrantes em São Paulo, local onde eram alojados gratuitamente os imigrantes até serem contratados pelos fazendeiros. ${ }^{31}$

A utilização de um local centralizado para receber os imigrantes em São Paulo também serviu, como apontou Petrone, como um espaço onde se contratavam os imigrantes, a exemplo de um mercado ${ }^{32}$, o que transformou a cidade "... num grande entreposto de mão-de-obra" ${ }^{33}$.

A Sociedade Promotora de Imigração deveria trazer apenas agricultores, conforme a expectativa dos fazendeiros paulistas, e os agenciadores, sabendo disso, embarcaram todos como agricultores.

\footnotetext{
${ }^{29}$ Ver sobre isso DEAN, Op. Cit., 1977 e em especial a iniciativa do Senador Vergueiro.

${ }^{30}$ ALENCASTRO, Luiz Felipe de; RENAUX, Maria Luiza. Caras e modos dos migrantes e imigrantes. In: ALENCASTRO, L. F. (org). História da Vida Privada no Brasil. São Paulo: Cia das Letras, 1997. v. 2.

${ }^{31}$ PETRONE, Maria Thereza Schorer. Imigração. In: HOLANDA, Sergio Buarque de; FAUSTO, Boris (Org.). História Geral da civilização Brasileira. São Paulo: Difel, 1977. Tomo III, v. 2

${ }^{32}$ Id. Ibid.

${ }^{33}$ SOUZA, Op. Cit., p. 58.
} 
Mas o que aconteceu é que nem todos que aqui chegaram eram trabalhadores rurais:

\begin{abstract}
Apesar do sucesso que agentes como Gaetano Pinto obtinham com suas falsas promessas de terra farta, registravam-se algumas reclamações de fazendeiros, pois entre os agricultores vinham também indivíduos que nada entendiam de lavoura e que, chegando em São Paulo, negavam-se a trabalhar no campo. ${ }^{34}$
\end{abstract}

Valentino Piovesan corrobora essa afirmação: "eu conheci de Treviso taberneiros, garçons, barbeiros, marceneiros, mas tiveram que ir lavrar o café." ${ }^{35}$

Boa parte dos vênetos e lombardos eram agricultores e sustentavam o sonho de retomarem a sua posição de pequenos proprietários, enquanto que os meridionais em sua maioria não tinham este mesmo anseio, e nem a vida no campo era seu ideal. Sua preferência era a cidade e muitos lutaram por ela. A especificidade da distribuição regional dos que vieram da Itália é fator determinante para estas preferências. Os vênetos, como vimos, se desfizeram de suas propriedades e vieram para o Brasil, enquanto os meridionais, acostumados aos pequenos e populosos burgos do sul da Itália, preferiam as cidades, onde poderiam reconstruir uma rede de amizades e relações pessoais, mesmo porque para esses meridionais a terra tornara-se "sinônimo de miséria e desespero". ${ }^{36}$

Alvim procura exemplificar essa preferência apontando a feição própria que a cidade de São Paulo adquiriu com a presença de meridionais e a localização de pequenos proprietários no interior paulista:

Talvez o melhor exemplo dessa divisão - confirmando a preferência de meridionais pela vida urbana - seja observar alguns traços deixados por essas comunidades na cidade de São Paulo: a Igreja de San Gennaro, da comunidade napolitana; a Igreja S. Vito Mártir, da comunidade baresa; a Igreja

\footnotetext{
${ }^{34}$ ALVIM, 1986, p. 45.

${ }^{35}$ FRANZINA, 1989, p. 187.

${ }^{36}$ ALVIM, Op. Cit., 1986, p. 71.

208 Revista de História Regional 15(1): 194-228, Verão, 2010
} 
N. S. Casaluce, também da comunidade napolitana e, finalmente, a de N. S. Aquiropita, da comunidade calabresa. Em contrapartida, a preferência vêneta pelo campo fica evidente nos numerosos sobrenomes vênetos entre os pequenos proprietários que integravam a Relação dos Proprietários dos Estabelecimentos Rurais Recenseados em 1920. ${ }^{37}$

E foi assim que as famílias Piovesan e Polese chegaram ao Brasil. A primeira atribulação aconteceu no desembarque. Giovanni comenta e alerta:

... cuidem bem que nos portos de mar há mal viventes que tentam pegar o dinheiro que trazemos no bolso. No meu navio foram roubados mais de um, quem 100 quem 200 liras ficaram despidos com toda a família, e estes bandidos fingem trocar o dinheiro mas fogem com ele. ${ }^{38}$

Desembarcando no porto de Santos, logo seguiram para a Hospedaria dos Imigrantes. Giovanni Polese deu entrada em 24 de fevereiro de 1888. Valentino Piovesan, em 21 de Janeiro de 1889. Lá ficaram até serem contratados para uma fazenda no interior de São Paulo. Receberam estadia, alimentação e assistência médica. Mas estes cuidados não sairiam de graça. $O$ seu débito ia aumentando: 9 passagens de navio da Itália para o Brasil ${ }^{39}$; translado de 9 pessoas mais a bagagem até São Paulo e a estada na Hospedaria. Somarse-iam ainda translado de toda a família até o interior e suprimentos (fornecidos pelo fazendeiro) para a sobrevivência até que recebesse o primeiro salário. O mesmo valia para Valentino. Só que eram 8 pessoas, e seu destino já estava certo: iria para a mesma fazenda que a irmã vivia há dois anos.

Paradoxalmente, a fuga da penúria iniciada na Itália tinha, pelo menos até o momento, se transformado em uma divida enorme.

\footnotetext{
${ }^{37}$ Ibid., p. 61.

${ }^{38}$ FRANZINA, Op. Cit., 1979, p. 151.

${ }^{39}$ A passagem custava em média 50 mil-réis (125 liras italianas) por pessoa. SCALABRINI, Op. Cit, 1979, p. 98.
} 


\section{Andiamo a San Carlo di Pigni ${ }^{40}$}

Giovanni Polese saiu da Hospedaria com contrato assinado com Paulino Carlos de Arruda Botelho. ${ }^{41}$ Iria para São Carlos do Pinhal trabalhar em sua fazenda de café, como já anunciara a canção: "andiano a raccogliere caffé". O contrato assinado era padrão e envolvia toda a família. Assim, famílias maiores, como é o caso de Polese, eram preferidas. Mais "braços" em um único contrato. O fazendeiro assumia a divida do imigrante para com a Sociedade Promotora de Imigração, tornando-se seu credor. Desta maneira, o imigrante e sua família ficavam presos ao fazendeiro.

O contrato padrão assinado era fruto de um longo processo que se iniciou em 1850, quando das primeiras tentativas de trabalho imigrante nas fazendas. É célebre na historiografia da imigração o caso Davatz. ${ }^{42}$ Em 1850, o senador Nicolau Vergueiro conseguiu trazer para a sua fazenda Ibicaba, em Rio Claro, 64 famílias, totalizando 432 pessoas de origem suíça. O sistema adotado foi chamado de parceria, apesar de caber ao proprietário a venda da produção. Entretanto, uma série de questões econômicas e sociais que envolviam o regime de trabalho acabou por desencadear uma

\footnotetext{
40 Os números da imigração em São Carlos não são fáceis de serem obtidos devido à inconstância dos dados estatísticos. Segundo Truzzi, entre 1884 e 1900, entraram no município 12.226 estrangeiros. Entre 1901 e 1920 entraram, segundo Madureira, 16.734 imigrantes, dentre os quais 3.532 italianos. Em 1920, $24,5 \%$ da população era composta de estrangeiros segundo Truzzi. A população de São Carlos, em 1920, era de 54.225 segundo Melo. MADUREIRA, Maria de Annunciação. Contribuição ao estudo da formação social de São Carlos. Seminário Casa do Pinhal. São Carlos: Associação pró-casa do Pinhal, 1999, p. 43. TRUZZI, Oswaldo. Mobilidade e política: considerações sobre a participação de imigrantes e seus descendentes em cidades médias do interior paulista. Teoria e Pesquisa, São Carlos, 32-35, p. 157-179, jan-dez 2000. TRUZZI, Oswaldo. Imigrantes italianos no interior de São Paulo: o caso de São Carlos. Seminário Casa do Pinhal. São Carlos: Associação pró-casa do Pinhal, 1999, p. 5. MELO, Vilmo Guimarães. A imigração Italiana e a transformação da estrutura econômico-social do município de São Carlos. Tese (Doutorado em Ciências Sociais), FFCL Marília - Unesp, Marilia, 1975, p. 120.

${ }^{41}$ FRANZINA, Op. Cit., 1979, p. 152.

42 DAVATZ, Thomas. Memórias de um colono no Brasil (1850). Belo Horizonte/São Paulo: Itatiaia/Edusp, 1980.
} 
revolta cujo porta-voz foi Thomas Davatz. Posteriormente, o mesmo escreveu um livro que foi publicado na Europa servindo como uma contrapropaganda da imigração. ${ }^{43}$

O contrato assinado na Hospedaria era um contrato pior que o primeiro contrato de Rio Claro, pelo menos para o imigrante. Era mais rigoroso, permitindo um controle maior por parte do fazendeiro, fruto das experiências anteriores. Enquanto que o contrato de Rio Claro era mais próximo de uma parceria, o de colono era um contrato de trabalho assalariado. familia?

Em que consistia o trabalho de Giovanni Polese e sua

Havia três tipos de trabalhador ligados diretamente à produção cafeeira: o empreiteiro, o colono e o camarada.

Antes mesmo do empreiteiro eram contratados "trabalhadores por turma" que tinham como função a derrubada das árvores e a queimada do terreno. Eram normalmente homens sozinhos, de origem nacional ou estrangeira. Ganhavam por mês ou por trimestre, além da comida. Quanto à habitação, improvisavam moradias com as árvores derrubadas. ${ }^{44}$

Ao empreiteiro cabia a formação do cafezal. As empreitadas eram trabalhos familiares. Envolviam a familia por um ano aproximadamente, desde a plantação das primeiras mudas até à primeira colheita. Apesar de ser um trabalho considerado economicamente viável, era necessário ter algum capital. Assim somente os italianos que imigraram com algum dinheiro é que conseguiam trabalhar na empreitada. ${ }^{45}$

Somente após a fazenda já pronta e produzindo é que começavam a trabalhar os colonos e os camaradas.

Giovanni Polese era colono. A Sociedade Promotora de Imigração, como foi visto, deveria trazer "braços" para a lavoura. Os italianos saíam da Hospedaria com um contrato de colonato já assinado.

${ }^{43}$ DEAN, Op. Cit., 1977.

${ }^{44}$ ALVIM, Op. Cit., 1986, p. 78.

${ }^{45}$ Ibid., p. 79. 
O colono e sua família eram responsáveis por aproximadamente dois mil pés de café para cada adulto, que consistiam na limpeza do cafezal, adubação, carpa do cafezal e colheita. Ainda cabia à família a plantação de outros gêneros como feijão e milho semeados entre as ruas de café. Sobre o café o colono recebia dinheiro das carpas e da colheita ${ }^{46}$. Já os demais gêneros plantados serviam para subsistência e o eventual lucro obtido na venda do excedente ficava com o colono.

Os camaradas eram normalmente trabalhadores nacionais que faziam serviços gerais na fazenda. Construção e reparo de cercas e outros insumos, ordenha do gado (quando houvesse), cuidados com as casas, enfim todo e qualquer serviço que não envolvesse o processo produtivo do café. ${ }^{47}$

Valentino Piovesan foi contratado como administrador da fazenda de Gioachino Ebren. Lá ele era responsável por vigiar toda a fazenda, inclusive o trabalho de 57 famílias que trabalhavam com o café. Exceção à regra, Valentino conseguiu um trabalho de boa remuneração (80 mil-réis por mês), muito provavelmente devido aos contatos de sua irmã Maria, que já estava nesta fazenda há cerca de dois anos. Seu pai e seu sobrinho foram trabalhar com o café, mas não com a capina e colheita, e recebiam um pagamento diário de 3 liras italianas por dia (1,2 mil-réis). A irmã Caterina que com ele veio conseguiu a colocação de camareira, com o salário de 30 mil-réis ao mês. Mas podemos perceber a proporção: para esta família correspondiam 57 famílias de colonos.

A única experiência exigida do colono e sua família era a de serem agricultores. Como vimos, nem sempre os agentes de imigração se importavam com isso ao arrebanhar italianos. Como ganhavam por número de estrangeiros que conseguiam trazer, não era incomum a vinda de pessoas que pouco ou nada conheciam do trabalho agrícola. Além disso,

${ }^{46}$ A remuneração em São Carlos para o ano de 1886 era 10 mil-réis pela capina de mil pés de café e 300 réis por cada alqueire (50 litros) colhido. MADUREIRA, Op. Cit., 1999, p. 46.

${ }^{47}$ SILVA, Aparecida de Paula; MACHADO, Micheli Santos. Os camaradas nas relações de produção levadas a efeito nas fazendas de café do oeste paulista. Trabalho de Conclusão de Curso (Graduação em História), Unicep, São Carlos, 2004. 
mesmo os que eram agricultores nunca tinham visto antes uma plantação de café, não estavam acostumados ao clima brasileiro e estranharam até mesmo a fauna local. Em resumo, nenhum colono tinha uma experiência válida para trabalhar nas fazendas paulistas.

Por muito tempo a historiografia da imigração insistiu em ressaltar o conhecimento do imigrante em detrimento do nacional. De onde teria partido essa interpretação? Novamente o discurso oficial foi tomado como base. A justificativa da imigração passava por um discurso de "falta de braços", mas também por um discurso civilizador. A ideia de que o trabalhador estrangeiro, em especial o italiano, tinha maiores conhecimentos que o nacional justificava a entrada de inúmeros imigrantes.

O caso dos fazendeiros fluminenses é exemplar. Enquanto que os fazendeiros paulistas insistiam em "falta de braços", experiência e cultura superior dos italianos, os fazendeiros fluminenses optavam pelo trabalhador nacional, pois este era de baixo custo, dotado de "sobriedade, docilidade, resistência as fadigas do trabalho e do clima, conhecimento dos sistemas de cultivo e de solo, e sem intenções de 'acumular fortunas e voltar para seus lares"'48. Para os endinheirados fazendeiros paulistas era interessante a criação de um exército de mão-de-obra de reserva, e tinham os meios necessários para tal. Para os decadentes fazendeiros fluminenses, a falta de dinheiro impossibilitava a importação de mão-de-obra e o nacional é então valorizado. O discurso variava conforme os interesses, necessidades e possibilidades de cada setor da elite.

Mas voltemos a Giovanni Polese e família, e sua pouca experiência no trato com o café. Teria ele enriquecido conforme prometia a propaganda imigrantista?

É bem provável que não. Segundo as análises de Warren Dean, entre os anos de 1885 e 1886, o salário médio

${ }^{48}$ SANTOS, Ana Maria dos Santos; MENDONÇA, Sonia Regina de. Representações sobre o trabalho livre na crise do escravismo fluminense, 1870-1903. Revista Brasileira de História, São Paulo, 6 (11), 1986, p. 89. 
anual de uma família na fazenda Santa Gertrudes era de 260 mil-réis. O saldo restante, deduzidos os adiantamentos era em média de 19 mil-réis. Para o período de 1886-7, o salário era de 230 mil-réis e o saldo era negativo em 41 mil-réis. Para $1887-8$, o salário era de 452 mil-réis e o saldo de 171 milréis. Para 1888-9, salário de 396 e saldo de 78 mil-réis $^{49}$.

Uma família como a Polese teria que trabalhar por cinco anos somente para pagar as dividas. Mas teria ainda que contar com a sorte. A doença ou a morte de um dos membros da família durante este período acarretaria em despesas e perda da capacidade de trabalho que levariam a mesma ao aumento das dívidas e consequente extensão do prazo.

Uma simples doença poderia transformar-se em um pesadelo. A ausência de um dos membros da família em época de colheita acarretaria em perdas de receita. Se a doença era mais grave e necessitasse um médico e remédios, o orçamento inteiro ficava comprometido, pois o pagamento de um médico era de aproximadamente 50 mil-réis. Sem contar o desgaste emocional e físico, pois os demais membros da família teriam que arcar com a carga de trabalho do convalescente. Até mesmo um casamento na família tornar-se-ia dificultoso; 30 mil-réis somente para a cerimônia. ${ }^{50}$

Comparado com o camarada, o colono sempre esteve em desvantagem. Em trabalho recente, Silva e Machado analisaram as condições de trabalho dos camaradas na fazenda Santa Maria. Utilizando os diários da própria fazenda entre 1914 e 1916, chegaram a conclusões bastante interessantes. A família do colono recebia à época aproximadamente 2 contos de réis (2000 mil-réis). ${ }^{51} \mathrm{Um}$ camarada recebia sozinho 2 contos e 500 mil-réis. Se fosse um pintor, seu salário seria

\footnotetext{
49 Dean aponta ainda que 5 de 12 famílias tiveram saldo negativo em 1885-6, 10 de 12 em 1886-87 e 3 em 1887. DEAN, Warren. Rio Claro: Um sistema brasileiro de grande lavoura 1820-1920. Rio de Janeiro: Paz e Terra, 1977, p. 167.

$50 \mathrm{O}$ valor de um médico, portanto, correspondia a aproximadamente $12 \%$ da renda familiar anual. Um casamento a $7 \%$. Esses dados podem ser vistos em DEAN, Op. Cit., 1977.

${ }^{51}$ Não podemos considerar esse valor como um aumento real de salário em relação ao que verificou Dean em Rio Claro, mas simplesmente uma correção do mesmo. DEAN, Op. Cit., 1977. 
de 6 contos de réis. Se carpinteiro, 5 contos de réis. Uma criança recebia 1 conto de réis. Isso individualmente. Uma família simples de camaradas poderia ganhar quatro vezes mais que uma família de colonos. Se fosse especializado, esse número subiria para cinco ou seis vezes mais. ${ }^{52}$

Não é sem razão que vemos poucos nacionais trabalhando como colonos nas fazendas paulistas no periodo. Enquanto o imigrante não conhecia as condições de trabalho e salário no Brasil, o nacional (normalmente ex-escravo) conhecia, e bem, estas condições, não se sujeitando, portanto a elas. ${ }^{53}$

A ausência de nacionais como colonos não pode ser interpretada simplesmente como uma forma de racismo por parte dos fazendeiros, como muitas vezes foi dito na historiografia. Antes devemos perceber o conhecimento prévio das condições de trabalho que tinha o elemento nacional e resistência em aceitar as mesmas. A marginalização do elemento nacional toma então outras perspectivas. De um lado, o camarada é marginal no sentido econômico, isto é, não atua no processo produtivo do café, mas nas margens deste sistema, construindo, pintando, reformando etc. De outro lado, nem todos os ex-escravos conseguiam ficar como camaradas nas fazendas. A migração para as cidades tornava-se então uma possibilidade de sobrevivência. Aqui a marginalização (entendida como a margem do sistema produtivo) do nacional torna-se até mesmo uma preocupação das autoridades. ${ }^{54}$

Mas e socialmente? Como era a vida de um colono italiano em São Carlos?

${ }^{52}$ SILVA; MACHADO. Op. Cit., 2004.

${ }^{53}$ Com relação a isso, ver MENDONÇA, Joseli Maria Nunes. Entre a mão e os anéis: a lei dos sexagenários e os caminhos da abolição no Brasil. Campinas: EdUnicamp, 1999.

${ }^{54} \mathrm{O}$ crescimento das cidades, causado principalmente pela migração interna, trouxe consigo preocupações para as autoridades. Questões sobre higiene, criminalidade e vadiagem foram temas constantes nos discursos das elites, que procuravam com medidas repressivas e educacionais manter o controle da situação. Ver entre outros, MORILA, Ailton Pereira. A escola da rua: cantando a vida na cidade de São Paulo (1870-1910). Dissertação (Mestrado em educação), FEUSP, São Paulo, 1999. 


\section{Abitare a San Carlo}

\section{Un infido e pesante lavor}

A família Polese podia se considerar afortunada. Logo ao chegar à fazenda de propriedade de Paulino Carlos de Arruda Botelho recebeu "uma posse de terreno, dois porcos, 8 cordeiros, uma vaca e alguns instrumentos" ${ }^{55}$. Ele mesmo procura explicar ao sogro como era o trabalho aqui:

Querido sogro explicarei como são as estações aqui no Brasil, nos primeiros dias de março recolhemos a nossa colheita, uma belíssima colheita. Em Outubro se plantam nossas colheitas tudo por nossa conta, por 4 lavras ao ano ganham-se 40 florins de cada 1000 plantas de café e aquilo que vem no meio é tudo por nossa conta. ${ }^{56}$

Os animais e instrumentos que recebeu seriam provavelmente computados em sua divida, mas pode ter sido a diferença entre a miséria e a sobrevivência. Em 1889, considerava sua situação boa:

Agora vos direi que neste ano temos uma boa colheita de favas e feijões por 3 anos; mas nós este excedente da colheita o vendemos, que aqui há comer como na Itália, e temos porcos e um animal de leite, e galinhas e frangos para comer e agora aqui se está bastante bem... ${ }^{57}$

Animado mesmo com sua situação se propôs a auxiliar Natalie e Alesso, seus cunhados, a imigrarem para a mesma fazenda, não como colonos, mas para trabalhar na fornalha ganhando 30 mil-réis por mês.

Melhor ainda parece ser a situação de Valentino Piovesan. Contratado como administrador da fazenda de Giochino Ebren, em São Carlos do Pinhal, recebia um salário de 80 mil-réis por mês ou duzentas liras italianas e ainda uma cesta de mantimentos bem ampla:

\footnotetext{
${ }^{55}$ FRANZINA, Op. Cit., 1979, p. 152.

${ }^{56}$ Ibid, p. 160.

${ }^{57}$ FRANZINA, Op. Cit., 1979, p. 159.

216 Revista de História Regional 15(1): 194-228, Verão, 2010
} 
Vuoi tu venire in Merica? Venturas e desventuras da imigração..

1 Quintal de milho

15 litros de arroz

10 quilos de açúcar

8 quilos de café

12 quilos de banha

15 quilos de carne

1 litro de óleo

2 litros de vinagre

4 litros de aguardente ${ }^{58}$

Sua irmã Caterina também trabalhava para o mesmo patrão, também com um serviço diferenciado: camareira, recebendo 30 mil-réis ao mês. Valentino provavelmente conseguiria realizar o seu sonho, que era voltar para a Itália daí a dez anos, onde poderia "passar os últimos anos sem preocupações" ${ }^{59}$

Mas tanto Valentino como Giovanni tinham consciência da excepcionalidade da situação. Valentino Piovesan era claro quanto a vir para o Brasil: "Isso lhe digo, que para fazer bem no Brasil é necessário ser chamado por parentes”, e continua, "a maior parte se arruínam quando se encontram na emigração ficam muito humilhados eles vão aos patrões para trabalhar mas todos precisam lavrar o café, tanto os artesãos quanto quem quer que seja". ${ }^{60}$

Segundo ele, a colheita de café era uma atividade pouco rentável e, portanto, deveria ser evitada. Conhecia bem as dificuldades da colheita, pois sua função como administrador da fazenda era "vigiar toda essa gente que vai todos os dias trabalhar o café." Cinquenta e sete famílias estavam sob seu olhar vigilante, o que indica uma proporção não muito animadora.

Giovanni Polese é ainda mais perspicaz:

Em imigração em São Paulo são 11 mil emigrantes e dormem no chão, apertados como as formigas, e comem mal e fazem maldições, o homem maldiz a mulher e a mulher maldiz o

58 Ibid., p. 186

${ }^{59}$ Ibid., p. 187

${ }^{60}$ Ibid., p. $186-7$. 
homem. E tantos vendem o que têm para vir ao Brasil, e depois ficam mal e enganados. Aqui sob o nosso patrão estão 8 famílias mas estas também maldisseram aquela vez em que partiram... ${ }^{61}$

E, apesar de se dispor a ajudar seus cunhados com a vinda ao Brasil, desde arrumar emprego até mesmo ir buscálos em São Paulo com seu próprio dinheiro, explica: "Olhem bem que na América não é como na Itália, no máximo no Brasil ouço dizer que há províncias onde estão bem, mas há tormentos por todo lado. Enfim eu não sei explicar-me melhor."62

Como última palavra afirma: "Arranjem vocês que eu não quero ser culpado de nada, que ficando em casa tem um efeito e saindo tem outro. É necessária paciência e coragem porque se está sujeito a tantas atribulações no dormir e no comer". ${ }^{63}$

Seus cunhados Natalie e Alésio vieram por fim, mas pouco ficaram. Resolveram tentar a vida em Buenos Aires, em um movimento comum aos imigrantes italianos.

Mas nem tudo foi fácil na vida de Valentino e Giovanni. De que reclamava Giovanni Polese? A primeira coisa que reclamava era a falta de vinho. Conforme ele mesmo diz, o importado é caro e o vinho fabricado no Brasil não se encontra para comprar na região. Pode parecer estranho alguém reclamar da falta de vinho, mas, como ele mesmo diz, o vinho é "aquilo que é mais necessário ao nosso corpo". A impossibilidade de manutenção de alguns hábitos culturais é uma das principais reclamações destes colonos. O vinho, hábito arraigado entre os camponeses italianos adquire nesse sentido uma forma de resistência.

Mas não se encerra aí: "outra coisa que temos de ruim é que não temos diversão, nem tabernas, nem igrejas, nem padres, e o pior é não ter médico por perto". Seus hábitos alimentares, tradicionais, sua vida social e religiosa deixaram

\footnotetext{
${ }^{61}$ Ibid., p. 160

${ }^{62}$ FRANZINA, Op. Cit., 1979, p. 151.

${ }^{63}$ Ibid., p. 151.

218 Revista de História Regional 15(1): 194-228, Verão, 2010
} 
de existir. Apesar de ter mantido seu núcleo familiar e conviver com outras famílias italianas, Giovanni Polese parece se sentir desamparado e abandonado culturalmente. E mesmo a correspondência que mantém com os parentes que ficaram na Itália (que escreve à noite, pois é o único momento que dispõe para tanto) está sujeita à censura:

...porque quando vem a correspondência do Brasil, nós não temos nenhuma; porque as cartas que vêm desta provincia muitas vezes são rasgadas por medo que caiam nas mãos de um outro patrão. Por isso não podemos ter correspondência; o patrão vai ele mesmo retirar o correio. ${ }^{64}$

Giovanni Polese encontrou, entretanto, um meio de burlar a censura de sua correspondência: pediu que a mandassem para outro remetente (um pseudônimo por certo) e diretamente à Estação Visconde de Rio Claro e não à fazenda. Assim quando fosse possivel ele iria retirá-las evitando assim que seu patrão as pegasse. Mais gastos, mais trabalho, dificuldade de manter um contato mais constante, mas, ao menos, ele conseguiu burlar a censura imposta pelo patrão, muito comum então.

Mas a vida era pior para muitos outros colonos, como sabia Polese.

Em agosto de 1887, um colono da província de Treviso, da qual não sabemos o nome, descreve um pouco as condições de vida em uma fazenda em Ribeirão Preto. Para começar explica que não há planície, mas "sítios montanhosos". E continua sua descrição:

Imagine 8 ou 10 casas distantes 16 ou 18 milhas de uma cidade; lá, caso adoeça, não se pode encontrar nem pão, nem médicos, nem remédios. Nas Fazendas pegam-se "bichos" nos pés, e posso dizer que não há italiano que eu conheça que na Fazenda não tenha tido doenças nas pernas ou nos olhos. Dir-vos-ei que na Fazenda não se encontram nem igrejas, nem padres, nem tabernas, nem loja nenhuma. ${ }^{65}$

\footnotetext{
${ }^{64}$ Ibid., p. 159.

${ }^{65}$ Ibid., p. 137.
} 
Dificil imaginar cenário mais distante do que Ribeirão Preto anunciado pela propaganda imigrantista:

O núcleo de Ribeirão Preto, próximo à aldeia homônima, distante da capital $417 \mathrm{~km}$, é atravessado pela linha ferroviária La Mogyana, e oferece aos imigrantes grandes vantagens pela prodigiosa abundância de seu solo, vasta extensão e esplêndido futuro, estando suas terras próximas de terrenos de pouco valor atualmente, mas de alto preço em poucos anos. Neste núcleo, os imigrantes encontram facilmente trabalho por dia. Todos estes núcleos são agrupamentos de um certo número de famílias agrícolas europeias, que ali se estabelecem para cultivar uma dada superficie de terreno, concedida a preço reduzido pelo Governo Provincial. O cultivo não é feito em comum; cada família cultiva o próprio terreno e entre uma e outra não existe outro vínculo além da vizinhança. Em cada núcleo existem escolas sustentadas pelo Governo. ${ }^{66}$

Promessa de terras, boa vizinhança, bons salários, independência e até mesmo escolas eram anunciados. Mas a grande maioria dos imigrantes trabalhava como colono, em condições pouco similares à propaganda.

As questões já apontadas de abandono, de desamparo são constantes nas cartas dos imigrantes italianos. Temos, entretanto, mais um problema: os bichos. Outro camponês de Creazzo, província de Vicenza que viveu em Santa Rita, mas mudou-se para uma fazenda em Descalvado, próximo a São Carlos, escreve em 1883. Segundo ele, saiu de um lugar feio e foi para outro pior. Reclama que ficou "8 dias doente com um tumor na mão" e os "bichos de pé são como formigas na Itália.", ou seja existem aos montes. O "bicho de pé" era um verdadeiro terror para esses colonos. Impossibilitava-o de trabalhar por dias e às vezes semanas, do contrário poderia infeccionar levando em alguns casos à morte. Mas não era só. Giovanni Polese alertava: "há os bichos e os vermes que se plantam na vida" e uma enorme quantidade de "mossatis", ou seja, mosquitos. Franzina nos explica:

66 Alla Provincia di São Paulo nel Brasile, 1886, p. 44 Apud FRANZINA, Op. Cit., 1979, p. 139

220 Revista de História Regional 15(1): 194-228, Verão, 2010 
O inseto que "se planta na vida" é com toda probabilidade o bicho berne capaz de cavar uma espécie de galeria sob a epiderme e de determinar portanto perigosos fleimões. (...) devem ser lembrados o carrapato e a mosca varejeira, um inseto que depositava os ovos nas cavidades auriculares ou nasais dos colonos causando, não raramente, sua morte ${ }^{67}$.

Não apenas os bichos atormentavam este colono de Descalvado:

... tenho que trabalhar com os pretos com sacos nos ombros montanhas acima como uma mula. De manhã se começa com as estrelas e à noite para casa com as estrelas.

A comida é de manhã feijão, ao meio-dia feijão, à noite feijão. A cidade é distante um dia de caminhada; a comida é cara. A aguardente tem bom preço: um franco e 25 o litro. Do resto tudo é caro. ${ }^{68}$

Parca alimentação (feijão, de manhã de tarde e a noite), comida cara, distância da cidade, longevas jornadas de trabalho (começa na madrugada quando ainda está escuro e termina à noite), trabalho pesado e preconceito de trabalhar com ex-escravos, fá-lo alertar: "de fato se há alguém que quer vir para o Brasil digam-lhe que fique na Itália mesmo." O Bispo Scalabrini revela mais alguns trechos de cartas:

Estamos desesperados, e grande parte morre de dor e fome.

Estou aqui na cruz, com sede, fome e traído! De 100 que éramos, estamos reduzidos a 40. Alguém perdeu o marido, outro a mulher ou um filho. E quem nos protege? Ninguém! Não temos nem juízes nem guardas! Os Senhores na Itália nos tratavam mal, mas na Itália estava-se melhor

Tinham-nos dito que aqui nascera e morrera Senhor Jesus Cristo, e que havia todos os presentes dos Reis Magos; ao invés, acabamos precisamente no inferno!

Dois dos nossos, por terem gritado foram amarrados, com uma corda ao pescoço, aos pés de um cavalo que percorreu

\footnotetext{
${ }^{67}$ FRANZINA, Op. Cit., 1979, p. 153.

${ }^{68}$ Ibid., p. 128.
} 
várias milhas; e o administrador, com um chicote na mão, obrigava-o a trotar e a galopar.

Vivemos aqui como bichos, sem sacerdotes e sem médicos. Nem mesmo se sepultam os mortos. Estamos pior do que cães presos à corrente. Dizei ao patrão que eu seria mais feliz em seu chiqueiro, na Itália, do que numa casa real, na América!"69

O colono de Ribeirão Preto havia concluído: "é preferivel ficar em uma prisão na Itália que em uma fazenda aqui...", a exemplo do chiqueiro. Já o colono de Descalvado resumiu: "Na América está uma merda..."70.

Por isso a decisão de muitos é escapar desta situação.

\section{Dove vai?}

Novamente a mobilidade torna-se a única arma para esses imigrantes escaparem das condições em que se encontram. A volta para a pátria é mantida como um horizonte a ser alcançado, mas outras possibilidades são tentadas. Nosso colono de Descalvado mudou de Santa Rita e observou que tudo se mantinha igual. Os cunhados de Giovanni, Natalie e Alessio foram tentar a vida em Buenos Aires. Outro país de atração era os Estados Unidos.

Quanto mais colonos fugiam, abandonavam simplesmente a fazenda, mais os fazendeiros vigiavam e pressionavam. Preocupados em manter sua mão-de-obra e não arcar com os prejuízos de uma divida não paga censuravam correspondência, impediam idas à cidade, contratavam "administradores" como Valentin para vigiá-los.

Mas a fuga não era facilmente impedida. Petrone afirma mesmo que a taxa de re-imigração, ou seja, a saída do Brasil estaria em torno de 40\%, apesar de faltarem dados sobre isso ${ }^{71}$.

\footnotetext{
${ }^{69}$ Ibid., p. 67-8.

${ }^{70}$ Ibid., p. 127; 137.

71 PETRONE, Op. Cit., 1977.

222 Revista de História Regional 15(1): 194-228, Verão, 2010
} 
Outro polo de atração para os imigrantes italianos eram as cidades. A historiografia, como vimos, mostrou que muitos dos imigrantes que aqui chegaram pouco ou nada conheciam do trato com a terra. Valentino Piovesan corrobora essa afirmação. Segundo ele, conheceu taberneiros, garçons, barbeiros, marceneiros contratados como colonos. Assim cidades como São Paulo mostravam-se promissoras em termos de sobrevivência, mesmo que o sonho de enriquecimento já se tivesse esvanecido. Dante dall'Ara instalou-se em São Paulo como relojoeiro e temos notícias suas através de um carta dirigida à sua irmã:

Tendo coincidência deste nosso amigo que tem a sorte de repatriar, mando-te estas poucas linhas para fazer conhecer a ti e também à nossa mãe que eu não me esqueci absolutamente de minha família, mas que força maior impede. Antes de tudo, tu farás saber à minha mãe que aqui na América os ganhos são mais míseros que na Itália, segundo que já sou casado há cerca de 4 anos e que tenho dois filhos, a primeira que conta 3 anos e o segundo menino que já tem mais de um ano $^{72} \cdot()$

A vida econômica, como podemos intuir dessa carta, não melhorava muito na cidade. Mas outras questões, sim. Dante se casou, teve filhos. Constituiu assim família e laços de solidariedade com vizinhos. Este processo não aconteceu sem conflitos, sofrimentos e resistências, como aponta Mori$1 \mathrm{l}^{73}$, mas ao menos trazia esperanças e uma vida societária para os envolvidos no doloroso processo imigratório.

A cidade de São Carlos também atraiu os italianos. Um anúncio de um "photographo", em 1886, denuncia isto:

PHOTOGRAPHIA ITALIANA DE BENJAMIN LACORTE - Rua do General Ozorio loja de Sabino \& Filhos - Tendo montado o seu atelier e tendo de demorar-se n'esta localidade por pouco tempo, participa ao respeitável publico que acha-se habilitado a tirar retratos pelo systema mais modemo "gelatim...

${ }^{72}$ FRANZINA, Op. Cit., 1979, p. 226-227.

${ }^{73}$ MORILA, Op. Cit, 1999. 
bromuro". Tira retratos todos os dias excepto os que chover, das 10 ás 3 horas da tarde. ${ }^{74}$

Ary Pinto das Neves relata a existência de concentração de imigrantes italianos no que ficou conhecida como "Piccola Calábria"75. Essa reunião em pontos específicos da cidade demonstra um tentativa de refazer ou reconstruir os laços societários. Assim, em São Paulo, o Brás, o Bexiga e o Bom Retiro passam a ser "bairros italianos" conforme os contemporâneos. Em São Carlos, a região delimitada pelos largos de Santa Cruz e da estação teria recebido este contingente.

Esse refazer dos laços societários pode também ser percebido na imprensa e nas associações e sociedades beneficentes do periodo.

Neves aponta para a existência, em 1891, do periódico "L'Italia", editado por Colombo e Valdiressa" ${ }^{76}$.

A Società Ginnastica Educativa Cristoforo Colombo era presidida por Giovanni de Simoni e David Cassinelli. A Società Meridionali Uniti Vittorio Emmanuele III foi fundada em 3 de agosto de 1900 e funcionava na Rua General Osório. Dela faziam parte calabreses, sicilianos, napolitanos, apúzios, abruces e lucanos, ou seja, um sociedade para os imigrantes do sul da península itálica. A Società Dante Alighieri, fundada em 15 de setembro de 1902, agremiava vênetos, lombardos, ligúrios, piemonteses, toscanos e romanos segundo Neves ${ }^{77}$. Essa última teve até mesmo uma escola para os filhos dos Imigrantes ${ }^{78}$.

Apesar da reconstituição de uma vida societária que o espaço da cidade possibilitava, os conflitos continuavam e até se acentuavam.

74 DAMIANO, Octávio Carlos. Imprensa são-carlense, 1876-1995. São Carlos: [s.n.], 1996, p. 19.

${ }^{75}$ NEVES, Ary Pinto das. São Carlos na esteira do tempo. São Carlos: [s.n.], 1984, p. 28.

${ }^{76}$ Id. Ibid., p. 29

${ }^{77}$ Id. Ibid., p. 29

${ }^{78} \mathrm{E}$ interessante perceber que essa escola, assim como outras, em outras localidades feria o projeto dos republicanos, sendo muitas vezes perseguidas. Ver MORILA, Ailton Pereira. Um monumento na avenida: a Escola Normal de São Carlos. Revista Histedbr On Line, Campinas, v. 19, 2005. 
Monsma apresenta alguns conflitos entre imigrantes e negros tanto na área rural quanto na área urbana da cidade. Questões ligadas ao trabalho, ao lazer, enfim, ao viver cotidiano, muitas vezes engendravam conflitos que acabavam em violência física. Foi num destes conflitos que o negro Angelo Antonio dos Santos foi alvejado com um tiro na perna esquerda pelo português João Bragado no carnaval de 1902 na fazenda Santa Evangelina. Em outro conflito, em área urbana, um mascate italiano foi morto por um negro após uma discussão na rua. A razão da briga, que ocorreu em 1895, teria sido a insistência de dois mascates italianos passarem em uma calçada que estava sendo assentada pelo negro Anastácio Cosme ${ }^{79}$.

O resultado dessa discussão, a morte de um e a prisão de outro e os motivos quase que irrelevantes denotam o estado de tensão existente na cidade.

Em outro caso, o português Narciso Dias da Silva esfaqueou o negro Manoel Batista, de 60 anos. A razão da briga era a cozinheira negra de 50 anos, Gertrudes Francisca de Paula que havia morado com os dois. ${ }^{80}$

Por vezes, o conflito irrompe coletivamente, como é no caso de um marujo que foi morto em Santos dentro de um navio italiano, em 1893, o que fez com que eclodissem na cidade de São Paulo conflitos sangrentos entre italianos e brasileiros, principalmente no bairro do Brás. Esse episódio, conhecido como a questão dos protocolos, se arrastou até 1896, quando Prudente de Morais assinou o chamado Protocolo, estabelecendo a indenização que o governo brasileiro daria ao governo italiano ${ }^{81}$. A extrema violência que esse episódio detonou faz crer que havia muitas rivalidades represadas que eclodiram na ocasião.

\footnotetext{
${ }^{79}$ MONSMA, Karl Martin. Mudança populacional e violência entre imigrantes e negros: São Carlos, 1888-1914. Anais do XVII Encontro Regional de História: o lugar da História. ANPUH/SP-Campinas, 6 a 10 de setembro de 2004. Cd-rom.

${ }^{80}$ Id. Ibid., p. 12

${ }^{81}$ PENTEADO, Jacob. Belenzinho, 1910 (retrato de uma época). São Paulo: Martins, [1962], p. 45.
} 
Nem todos os conflitos terminavam, porém, em violência, mas as rivalidades, desconfianças e preconceitos estavam no dia a dia da população como demonstra uma quadrinha comum na cidade de São Paulo:

\section{Carcamano, pé-de-chumbo \\ Calcanhar de frigideira \\ Quem te deu a confiança \\ De casar com brasileira ${ }^{82}$}

A quadrinha mostra a desconfiança do elemento nacional para com o estrangeiro, notadamente o italiano, o "carcamano", alcunha que por si só é pejorativa, denotando a pouca honestidade do italiano. ${ }^{83}$

As faces desse conflituoso processo de integração do imigrante à vida brasileira são muitas. São perceptíveis não apenas na violência física, mas até mesmo em músicas, ditados e conselhos diversos. Como na preconceituosa sugestão para se jogar no bicho, um jogo de apostas em dinheiro, surgido em 1892. Jogava-se no porco se no sonho aparecesse um italiano; no camelo, caso se sonhasse com um turco; no cavalo, se fosse um inglês; no touro ou vaca, se espanhol ou espanhola, e, no burro, se aparecesse um português. ${ }^{84}$

As autoridades criaram leis, códigos e instituições na tentativa de regular o espaço urbano. Muitos imigrantes italianos, conforme afirma Martins e Dias, foram recolhidos ao "Asylo Dona Maria Jacynta", em São Carlos ${ }^{85}$. Longe de ser uma instituição caridosa, era uma verdadeira prisão, onde muitas pessoas, imigrantes ou não, acabaram por morrer, a exemplo do que ocorria em muitas cidades brasileiras.

\footnotetext{
${ }^{82}$ MACHADO, Antonio de Alcantara. Novelas Paulistanas. 5. ed., Rio de Janeiro: José Olympio, 1978.

${ }^{83}$ Segundo Jacob Penteado, a palavra carcamano teria sua origem na expressão carca la mano, expressão que o comerciante italiano dizia ao seu filho quando este pesava alguma mercadoria e faltavam ainda algumas gramas para completar o peso. PENTEADO, Op. Cit., p. 44.

${ }^{84}$ Id. Ibid., p. 289.

${ }^{85}$ MARTINS, Luciane; DIAS, Renata Cristiano Lopes. Mendigos no asilo: a segre gação social na cidade de São Carlos nas primeiras décadas do século XX. Trabalho de Conclusão de Curso (Graduação em História), Unicep, São Carlos, 2005. 
O processo de imigração não foi tão harmonioso como queria a elite republicana e como procurou mostrar a historiografia oficial. Não foi fácil nem para os imigrantes, nem para os nacionais. Os conflitos, resistências, convivências e trocas são facetas inseparáveis deste processo que nos legou histórias e memórias, pizzas e salames, um linguajar um tanto quanto cantado, que se somou ao falar arrastado do caipira. E o ciao, devidamente abrasileirado para "tchau".

Mas voltando aos nossos protagonistas. Não sabemos se Giovanni, Valentino ou o imigrante anônimo de Descalvado se envolveram em conflitos. Mesmo que não, é bem provável que eles tenham presenciado algum ou sofrido com comentários preconceituosos.

E o que lhes aconteceu? Ficaram em São Carlos? Voltaram para a Itália? E seus filhos, abrasileiraram-se? Não sabemos ao certo. Consultando a lista telefônica da região encontramos duas pessoas com sobrenomes Polese e quinze com sobrenomes Piovesan. Uma posterior pesquisa poderá revelar o destino desses dois imigrantes que nos acompanharam até aqui.

Por enquanto, sabemos pouco. E o pouco que sabemos esta aí, nas cartas que mandaram para seus familiares na Itália, e que Franzina compilou. Sabemos que sofreram e que lutaram por sua sobrevivência como todos os imigrantes que aqui chegaram. Assim como eles são muitos Giuseppes, Giulias, Giovanas, Abramos, Titos, Vittorias, Diogenes, Domenicas...

\section{Vuoi tu venire in Merica? Venturas e desventuras da imigração italiana em São Carlos}

Ailton Pereira Morila

Resumo: utilizando canções, poemas e cartas, este artigo busca reconstituir a trajetória de alguns imigrantes italianos. Desde as razões para emigrar da Itália, a influência da 
propaganda imigrantista na escolha do Brasil como destino, a chegada em São Paulo na Hospedaria dos Imigrantes até o encaminhamento para fazendas na região de São Carlos, interior de São Paulo. Como viveram, as dificuldades que enfrentaram na região, enfim, as venturas e desventuras do viver em São Carlos completam a trajetória destes imigrantes que em algum momento de suas vidas responderam sim a pergunta: você vai para a América?

Palavras-chave: imigração italiana; São Carlos (SP); cartas de imigrantes; trabalho.

Abstract: using songs, poems and letters, this article seeks to retrace the path of some Italian immigrants. Since the reasons for emigrating from Italy, the influence of immigrant advertising in the choice of Brazil as a destination, the arrival in São Paulo at the Inn of Immigrants until the trip to the farms in the region of São Carlos, São Paulo. How they lived, the difficulties they faced in the region, and finally the fortunes and misfortunes of living in San Carlos complete the trajectory of immigrants who at some point in their lives answered yes to the question: Do you go to America?

Keywords: Italian immigration; São Carlos (SP, Brazil); letters from immigrants; work.

Recebido em: 23/04/2010

Aprovado em: 24/06/2010 